\title{
Prospects for the Development of Cryptocurrency Regulation in Singapore
}

\author{
Julia Shabatuk
}

\author{
Master's student, \\ International Finance Faculty \\ Financial University, Moscow, Russia \\ yshabatyuk@bk.ru
}

Abstract

In this article are discussed the main prospects of development of cryptocurrency in Singapore, as it is widespread and used all over the world. The article covers the main points for the regulation of the cryptocurrency. There is a wide range of cryptocurrency trading platforms, and most of them are located in different countries, which leads to significant differences in terms of regulation by the authorities and, accordingly, different rules for users and companies. Several exchanges allow trading derivatives. A more detailed review would give a correct impression of the current situation in the world in terms of regulation of cryptocurrencies and future trends. Cryptocurrencies continue their development; the number of users of cyber money is steadily growing. The popularity of bitcoin has generated the creation of other cryptocurrencies that are developing along with bitcoin, but their popularity and capabilities are much less. In some countries, including Russia, the government started warning people that investing in "cash" equivalents could lead to losses in case if there is a collapse of cryptocurrency (bitcoin).

Keywords: cryptocurrency; regulations; finance; Singapore; bitcoin; derivatives; blockchain; trade; government JEL classification G 19, G29

S ingapore expresses one of the most controversial views on the legal regulation of cryptocurrencies. Singapore is a city-state with a form of government in the form of a parliamentary Republic. Officially, the country has a multi-party system, but in fact, opposition parties are practically not represented in Parliament. However, government policy is fairly transparent, and corruption is virtually non-existent. The country has one of the lowest crime rates in the world. The population of the country is about 5.5 million people. The national currency is the Singapore dollar.

Until 2014, bitcoin had no official status in Singapore. However, later, there was a need to regulate the turnover due to the increase in the percentage of capitalisation of the cryptocurrency. The tax authorities have developed a complex system of identification of digital currency in a wide range of different financial transactions.

- Companies engaged in the exchange (purchase and sale) of bitcoins are required to pay a tax of 7 per cent of the profits received when performing these operations. A similar tax rate is applied to the taxation of profit in the sale of goods and services. Thus, like most Western countries, the Republic of Singapore equated cryptocurrency to property obligations.

- Long-term investment in BTC is not taxed, that equates to the transaction data to the investment in the capital. Thus, BTC is equivalent to currency, but the official status of the bitcoin received. It provokes the legally suspended state of the cryptocurrency and the inability to fully apply the current financial legislation of Singapore. 


\section{$(S O D)$}

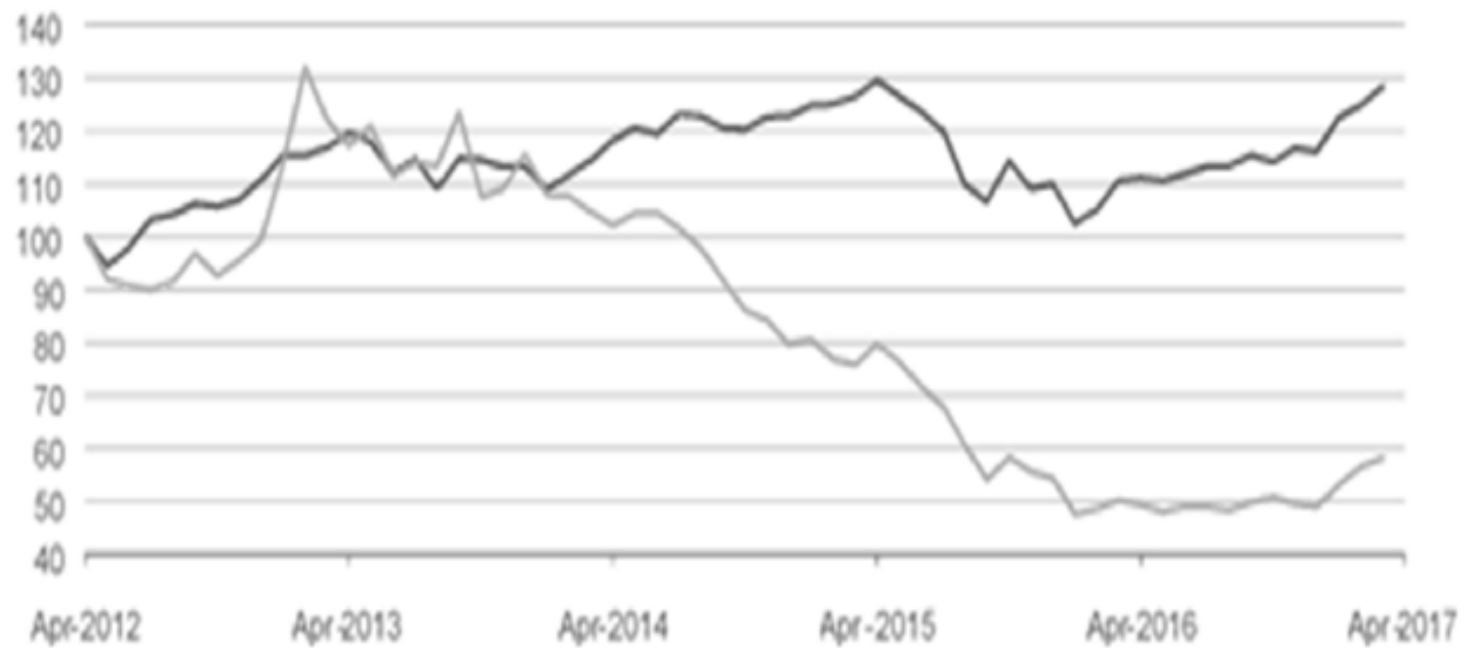

Fig. 1. Diagram FTSE ST Catalist Index Volatility (Singapore).

Source: FTSE Group, Singapore Exchange.

- When paying for goods and services by Singapore citizens, a tax similar to the one described in the first paragraph in the amount of 7 per cent is charged, that is, bitcoin can again be considered only as property obligations. Thus, it is not about paying for goods and services in the conventional sense of the word, but about barter. The seven per cent tax rule does not apply to non-residents of the country. In October 2017, the Minister of the economy and social policy Tarman Shanmugaratnam, who is also the Chairman of the financial regulator of Singapore, made an official statement that the cryptocurrency is not a legitimate means of payment, but a means of exchange.

- Payment for virtual goods and services (games, applications, etc.) is not taxed at 7 per cent.

- With the release of ICO in token of the digital type with the assignment of the status of the securities regulation of their circulation shall be in accordance with the applicable laws of Singapore in respect of securities. For holders of digital securities who are individuals and whose activities are not related to profit from the purchase/sale of securities, there is no tax, including the single sale of this type of asset. However, legal entities and individuals, whose activities are related to the purchase/sale of securities for profit, are subject to income tax in the amount of 17 per cent of the income received.

In March 2014, the government of Singapore delegated to the monetary authority of the country to provide measures of control over virtual currencies in connection with the anonymity of the latter and the possibility of using them for money laundering and for sponsoring terrorism or other illegal activities. Companies that exchange digital currencies for real currencies must ensure the identification of users and are obliged to transfer information to law enforcement agencies in the event of a suspicious transaction.

In December 2017, the Deputy Prime Minister for economy and social policy Tarman Shanmugaratnam expressed an opinion that fully describes the regulation of digital currencies and expresses the attitude to the problems on the part of the government of Singapore: "the State does not directly regulate cryptocurrencies but deals with the legitimate coordination of the activities of ISO, that is, companies engaged in the production, storage, purchase and sale of cryptocurrencies."

At the end of 2017-the beginning of 2018, several ISO companies based in Singapore 


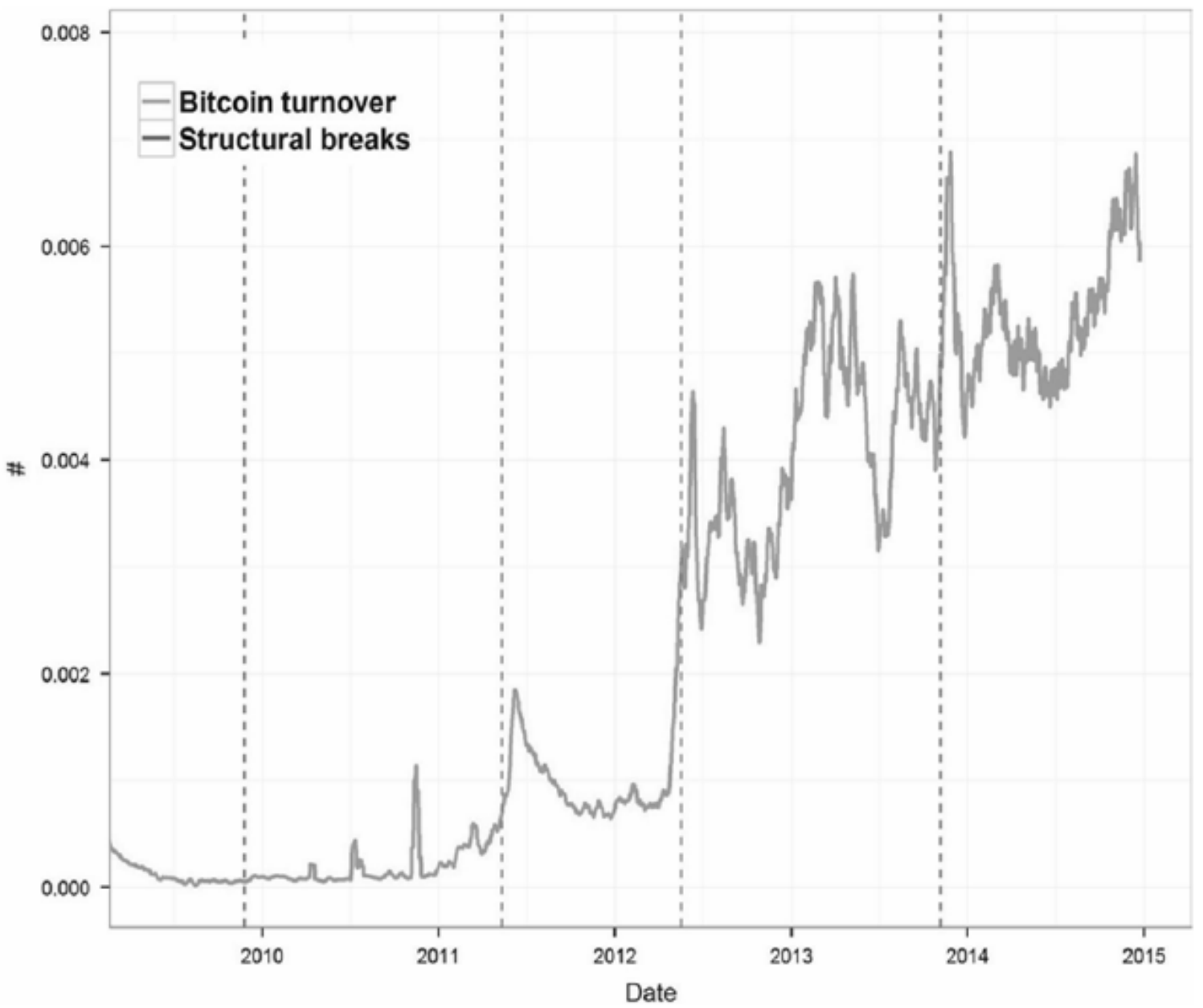

Fig. 2. Crypto-Turnover ratio.

Source: Singapore Department of Statistics.

were frozen accounts in local banks, due to the uncertain legal status of digital currencies or non-compliance with legislation on securities turnover, to which several tokens were equated.

As of May 2018, there were no significant changes in this issue. On the territory of Singapore today there are a little more than 20 points of physical trade in which payment for goods and services can be made using BTC. An interesting fact is that against the background of these events in Singapore, however, actively introduced physical cold wallets (plastic card with a microchip) with an account in BTC (the amount of the account is fixed in accordance with the specified nominal value of Satoshi at the time of sale). Today, wallets with a nominal value of $0.01 \mathrm{BTC}$ and $0.05 \mathrm{BTC}$ are available for sale. The cost in us dollars as for April 29, 2018, was 96 and 480 dollar respectively.

Digital currencies recognised as legal tender with monetary unit status are not currently available in Singapore. The only cryptocurrency in respect of which official statements are made, which significantly increases the status of trust in it, is bitcoin, which acts in the form of property obligations or securities. There were no statements from the government of Singapore regarding other types of digital currencies. However, the head of the MAS Tharman Shanmugaratnam in their official public statements referred to the possibility of the emergence of new tokens, in respect of which would also apply to legislative rules are identical to regulations on bitcoins. 
The monetary authority of Singapore (MAS), which serves as the Central Bank, has introduced updated rules for enterprises attracting financing through initial coin offerings (ICO). Initially, MAS MADE changes to the existing rules of ICO regulation adopted by the office last year. The changes concerned the legal regime for payments and clarified the Central Bank's position on how intermediaries should comply with the anti-money laundering (AML) and anti-terrorist financing standards. By intermediaries, we mean any individuals and legal entities involved in the ICO: from those who issue tokens to those who provide financial advice.

According to the MAS RULES, issuers of tokens distributed within the ICO must have a license for services in the capital markets, financial consultants - a license of a financial adviser, and platforms for trading digital assets - a license for operations with securities. The changes to the rules state that all these intermediaries are required to take action to identify, assess and understand the risks associated with money laundering and the financing of terrorism. Also, all participants must develop and implement meet the requirements of MAS procedures for the verification and control of customer transactions, based on records of their transactions.

According to the rules, even if the token is not a security, all actions with it should be carried out in accordance with AML-procedures. If you suspect a terrorist connection, such enterprises will engage the office of security and intelligence agencies of Singapore and the relevant division of the United Nations (UN). Also, in November, MAS presented a new bill on payment services (PSB), which included cryptocurrencies. They are now subject to the General rules for domestic and international remittances. Also, PSB is mentioned in the updated provision of ICO.

It is worth noting that in October, MAS told about the intention to ensure that banks in Singapore began to provide services to companies whose activities are related to cryptocurrencies. According to the representatives of the Department, it is necessary for the development of the financial and technological industry in the state.
According to the information collected by $\mathrm{CB}$ Insights, Funderbeam and Crunchbase, 57 per cent of ICO funding are now concentrated in 5 countries: the US, Switzerland, Singapore, Canada and the UK. ICO funding has also increased over the past year by almost 47 times (according to Coinschedule from 70 million to 3.3 billion). According to the analytical company Blockchain Elementus, Singapore attracts more and more blockchain startups, and in August 2018, for the first time bypassed the US in terms of the number of ICOS held in its jurisdiction.

The gradual strengthening of control in the States leads to the fact that young crypto companies are looking for more favourable conditions for launching projects. Although it is impossible to say for sure, whether this trend will continue in the future, the government of Singapore has begun to restructure the legislative framework for the full regulation of the ICO market.

Elementus analysts estimate that the market of primary placements at the beginning of September attracted about $\$ 28.4$ billion. It also claims that, despite the General crisis of the crypto market, the ICO market is now at a level comparable to last year. In August last year and this year, an almost equal amount of investment ( $\$ 1.4$ billion) was attracted. From February to August this year, $\$ 15.9$ billion was collected, despite the bearish trend.

The company notes the growing competition among startups and a more selective approach from all groups of investors. It led to a decrease in the share of projects that were able to raise more than $\$ 100$ thousand, from 84 per cent to 22 per cent.

There are different prospects of cryptocurrency regulation in Singapore. For instance, the use of a cryptocurrency company in Singapore to enter the ICO is considered to be the best option, since it is quite easy to conduct business in the country. This city-state is one of the few that has friendly legislation in relation to cryptocurrency activities. In Singapore, you can develop almost any projects related to innovation, as well as startups related to the technology of blockchain, cryptocurrencies, ICO. 


\section{References}

Khamenushko, I. V. (2017). Kriptovalyuty i ikh maining kak ekonomicheskaya real'nost': predposylki pravovogo regulirovaniya [Cryptocurrencies and their mining as economic reality: prerequisites of legal regulation]. Zakonodatelstvo.

Shcherbik, E. E. (2017). Fenomen kriptovalyut: opyt sistemnogo opisaniya [Phenomenon of crypto-currencies: the experience of the system description]. Nauchno-metodicheskii elektronnyi zhurnal «Kontsept», S 1 , 56-64. Retrieved from http://e-koncept.ru/2017/470010.htm.

Ageev, A. I., Loginov E. L. (2018). Kriptovalyuty, rynki i instituty [Cryptocurrencies, markets and institutions]. Ekonomicheskie strategii. Retrieved from http://www.inesnet.ru/article/kriptovalyuty-rynki-i-instituty/.

Lagutenko, A. (2018). Kriptovalyuty. Pravila primeneniya [Cryptocurrencies. Rules of application]. Nauka i zhizn, 2. Retrieved from https://www.nkj.ru/archive/articles/33121/.

Riss, V. I. (2017). K voprosu o kollektivnykh valyutakh ili chastnykh dengakh [On the issue of collective currencies or private money]. In "Ekonomika, upravlenie i pravo: innovatsionnoe reshenie problem". http://asiavector.ru/countries/singapore

\section{Перспективы развития регулирования криптовалюты в Сингапуре}

\section{Юлия Шабатюк}

студентка магистратуры,

Международный финансовый факультет,

Финансовый университет, Москва, Россия

Аннотация. В статье делается попытка определить перспективы развития криптовалюты в Сингапуре, учитывая широкое распространение и использование криптовалют во всем мире. Автор рассмотрел порядок и методы государственного регулирования рынка криптовалют, дал характеристику некоторым криптовалютным торговым платформам, большинство из которых расположены в разных странах, что приводит к существенным различиям в плане регулирования со стороны властей и, соответственно, разным правилам для пользователей и компаний. Обобщены принципы работы бирж, где разрешено торговать деривативами. Оценивая развитие и рост рынка криптовалют, количество пользователей киберденьгами, автор отмечает, что популярность биткоина породила создание других криптовалют, которые развиваются наряду с ним, но их возможности существенно ограничены. В некоторых странах, в том числе и в России, власти предупреждают людей, что инвестирование в «денежные» эквиваленты может привести к убыткам в случае краха криптовалюты.

Ключевые слова: криптовалюта; регулирование; финансы; Сингапур; биткоин; деривативы; блокчейн; торговля; правительство 